OPEN ACCESS

Edited by:

Ana Colaço,

Marine Research Institute (IMAR)

Portugal

Reviewed by:

Daniel Yule,

United States Geological Survey (USGS), United States

Rui Pedro Vieira,

Centre for Environment, Fisheries

and Aquaculture Science (CEFAS),

United Kingdom

*Correspondence:

Ryan P. Bos

Rbos2019@fau.edu

Specialty section:

This article was submitted to

Deep-Sea Environments and Ecology,

a section of the journal

Frontiers in Marine Science

Received: 16 September 2020 Accepted: 04 February 2021

Published: 25 February 2021

Citation:

Bos RP, Sutton TT and Frank TM (2021) State of Satiation Partially

Regulates the Dynamics of Vertical Migration. Front. Mar. Sci. 8:607228.

doi: 10.3389/fmars.2021.607228

\section{State of Satiation Partially Regulates the Dynamics of Vertical Migration}

\author{
Ryan P. Bos ${ }^{1 *}$, Tracey T. Sutton ${ }^{2}$ and Tamara M. Frank ${ }^{2}$ \\ ${ }^{1}$ Harbor Branch Oceanographic Institute, Florida Atlantic University, Fort Pierce, FL, United States, ${ }^{2}$ Halmos College \\ of Natural Sciences and Oceanography, Dania Beach, FL, United States
}

Vertical migrations into shallower waters at night are beneficial for migrators as they reduce predation risk and allow migrators to encounter a higher density of prey. Nevertheless, ocean acoustics data and trawl data have shown that a portion of some vertically migrating populations remain at depth and do not migrate. One hypothesis for this phenomenon is the Hunger-Satiation hypothesis, which in part states that the non-migrating portion of the migrating species-assemblage refrains from migrating if they have full or partially full stomachs from daytime or nocturnal feeding. However, stomach fullness of the non-migrating subpopulation compared to the migrating portion has rarely been studied, due to the difficulty in obtaining sufficient samples. The stomach fullness levels of numerically abundant crustacean and fish species with wellknown depth distributions were quantified in the present study. Animals were captured during night trawls from discrete-depth intervals between 0 and 1,500 m. Stomach fullness indices were assigned from 0 to 5 and compared between migratory taxa caught in shallow and deep waters. Data from the crustaceans Acanthephyra purpurea, Gardinerosergia splendens, Plesionika richardi, and Systellaspsis debilis, as well as the fishes Lampanyctus alatus, Lepidophanes guentheri, and Notolychnus valdiviae, provided support for the Hunger-Satiation hypothesis, while data from the crustaceans Gennadas capensis and Gennadas valens and the fish Benthosema suborbitale did not. These findings suggest that stomach vacancy may be just one of several factors regulating the dynamics of vertical migration in those species whose behavioral plasticity suggests daily "choices" in whether or not to vertically migrate.

Keywords: diel vertical migration, hunger-satiation hypothesis, state of satiation, stomach fullness, micronekton

\section{INTRODUCTION}

In all oceans, massive assemblages of deep-pelagic organisms undergo vertical migrations to shallower epipelagic waters at night. This migration behavior is referred to as diel vertical migration (DVM), and it is the largest animal migration on Earth in terms of abundance and biomass (rev. in Longhurst, 1976; Gjøsaeter and Kawaguchi, 1980; Cohen and Forward, 2005). The migratory assemblage comprises a variety of deep-sea biota, many of which are micronektonic (2$20 \mathrm{~cm}$ ) crustaceans and fishes. DVM is beneficial because animals ascending to forage in surface waters at night encounter a larger prey density and do so under the cover of darkness, thereby reducing predation by visual predators (Foxton and Roe, 1974; Clark and Levy, 1988; Bollens and Frost, 1989). This phenomenon is controlled by a variety of exogenous and endogenous factors, 
with light generally regarded as the primary proximate driver triggering and controlling the extent of the vertical migration (Clarke, 1930; Ringelberg and van Gool, 2003; rev. in Cohen and Forward, 2005). In addition to light, however, DVM behavior can also be affected by a variety of other external factors such as currents (Bennett et al., 2002), tidal cycle (Hill, 1991), lunar cycle (Alldredge and King, 1980), food availability (Huntley and Brooks, 1982), as well as internal factors such as feeding periodicity (Mullin, 1963), circadian rhythms (Haney, 1993), and state of satiation (Waterman et al., 1939; rev. in Cohen and Forward, 2005). These factors may alter migration patterns between species and among individuals of the same species, leading to the observed lack of synchrony between migrators of the same species (rev. in Forward, 1988).

After feeding in shallow waters at night, vertical migrators descend back to cold, deep-pelagic waters, where they digest and defecate. In doing so, they contribute to active-nutrient flux by expediting the flux of carbon, nitrogen, and phosphorus to deeper waters (Dam et al., 1995; Hidaka et al., 2001; Steinberg et al., 2002, 2008) and are therefore important for biogeochemical cycles. The studies by Steinberg et al. $(2002,2008)$ demonstrated that sinking particulate organic carbon could supply only a portion of the carbon required by the zooplankton community in the mesopelagic realm. They argue that a significant fraction of the excess $\mathrm{C}$ demand can be transported by migrating zooplankton via excretion (DOC) and respiration (inorganic C). A variety of field studies suggest that up to $45 \%$ of the flux of organic particles from surface to deeper waters may be due to transport by vertically migrating zooplankton that feed at the surface and actively respire and excrete waste products at depth (rev. in Bollens et al., 2011; Bianchi et al., 2013). In some cases, the biogeochemical impact of DVM is extreme, as consumption of oxygen in shallower waters by deep-pelagic organisms may intensify oxygen depletion in oxygen minimum zones (Bianchi et al., 2013).

Acoustic backscattering and trawl data have shown that in some cases, a portion of migrating populations undertake a nocturnal ascent, while the other portion remains at depth (Youngbluth et al., 1989; Onsrud and Kaartvedt, 1998; Kaartvedt et al., 2012). Cessation of migration during nocturnal feeding periods has been documented in both shrimp and fishes (Roe, 1984; Hopkins et al., 1994; Kaartvedt et al., 2009) and during periods of high food availability such as spring phytoplankton blooms (Geller, 1986). Refraining from migrating into more productive waters during periods of decreased predation pressure is counterintuitive. However, one factor that has been hypothesized to play a major role in regulating migratory behavior is state of satiation. Clarke (1934), Kozhov (1947), and Ponomareva (1971) all suggested that state of satiation had a strong influence on the migration behavior of various crustaceans, and these observations formed the basis of the Hunger-Satiation hypothesis (Simard et al., 1985; Atkinson et al., 1992; Gibbons, 1993). According to this hypothesis, a hungry individual might push the upper limit of the light envelope by migrating earlier in order to enhance its chances of obtaining prey, which would also make it easier for predators to find, while a better-fed individual might be less willing to expose itself to these higher light levels. Hunger/satiation could also explain these bimodal population distributions, in that some individuals, having fed the night before or sufficiently at depth during the day, would remain in safer, deeper depths at night (rev. in Pearre, 2003). Laboratory studies of Euphausia superba show that state of satiation alters their locomotory behavior, with full guts associated with decreased swimming and a quiescent state (Tarling and Johnson, 2006). Stomach fullness data are sparse and conflicting for micronektonic crustaceans and fishes (Donaldson, 1975; Hu, 1978; Roe, 1984), with some studies indicating that they fed throughout their entire depth distribution and others showing that they apparently fed only in surface waters during their nocturnal migrations.

After the largest oil spill in history, Deepwater Horizon (2010), numerous trawl surveys were conducted in 2011 and again in 2015-2017 to study deep-pelagic communities and potential consequences of the spill. A large number of samples were collected from a variety of depths, which presented an unprecedented opportunity to observe "natural" variations in migration patterns and predicted anthropogenic influences. We utilized specimens collected during these cruises, to conduct an analysis of the correlation between state of satiation and vertical migration behavior. We analyzed the stomach fullness of 10 species of migrating and non-migrating individuals of migratory fishes and shrimps, as well as compared the migration behavior of 14 crustacean species collected at discrete depths.

\section{MATERIALS AND METHODS}

Crustacean and fish samples were collected in the GoM over a span of 6 years on cruises aboard the M/V Meg Skansi in 2011, as part of the Offshore Nekton Sampling and Analysis Program (ONSAP), and R/V Point Sur in 2015-2017, as part of Deep Pelagic Nekton Dynamics of the Gulf of Mexico (DEEPEND) Consortium research (Sutton et al., 2020). The sampled stations coincide with pre-established locations and nomenclature of the Southeast Area Monitoring and Assessment Program sampling grid (Figure 1).

Samples were collected using a $10-\mathrm{m}^{2}$ Multiple Opening and Closing Net and Environmental Sensing System (MOCNESS) equipped with 3-mm nylon mesh nets (Wiebe et al., 1976). Samples were gathered from five discrete depth ranges: 0-200; 200-600; 600-1,000; 1,000-1,200; and 1,200-1,500 m. Sampling was conducted at each station during daytime, centered at solar noon, and nighttime, centered at midnight. Crustaceans and fishes were fixed in $10 \%$ formalin and sent to the Oceanic Ecology Laboratory (fishes) and the Deep-Sea Biology Laboratory (crustaceans) at Nova Southeastern University for identification and analysis.

\section{Sample Processing}

After species identifications were complete, the wet mass of crustaceans and fishes was measured to the nearest $0.01 \mathrm{~g}$ (P114 balance, Denver Instruments). Carapace length (decapod crustaceans), body length (euphausiids), and standard length (fishes) were measured to the nearest $0.1 \mathrm{~mm}$ using digital 


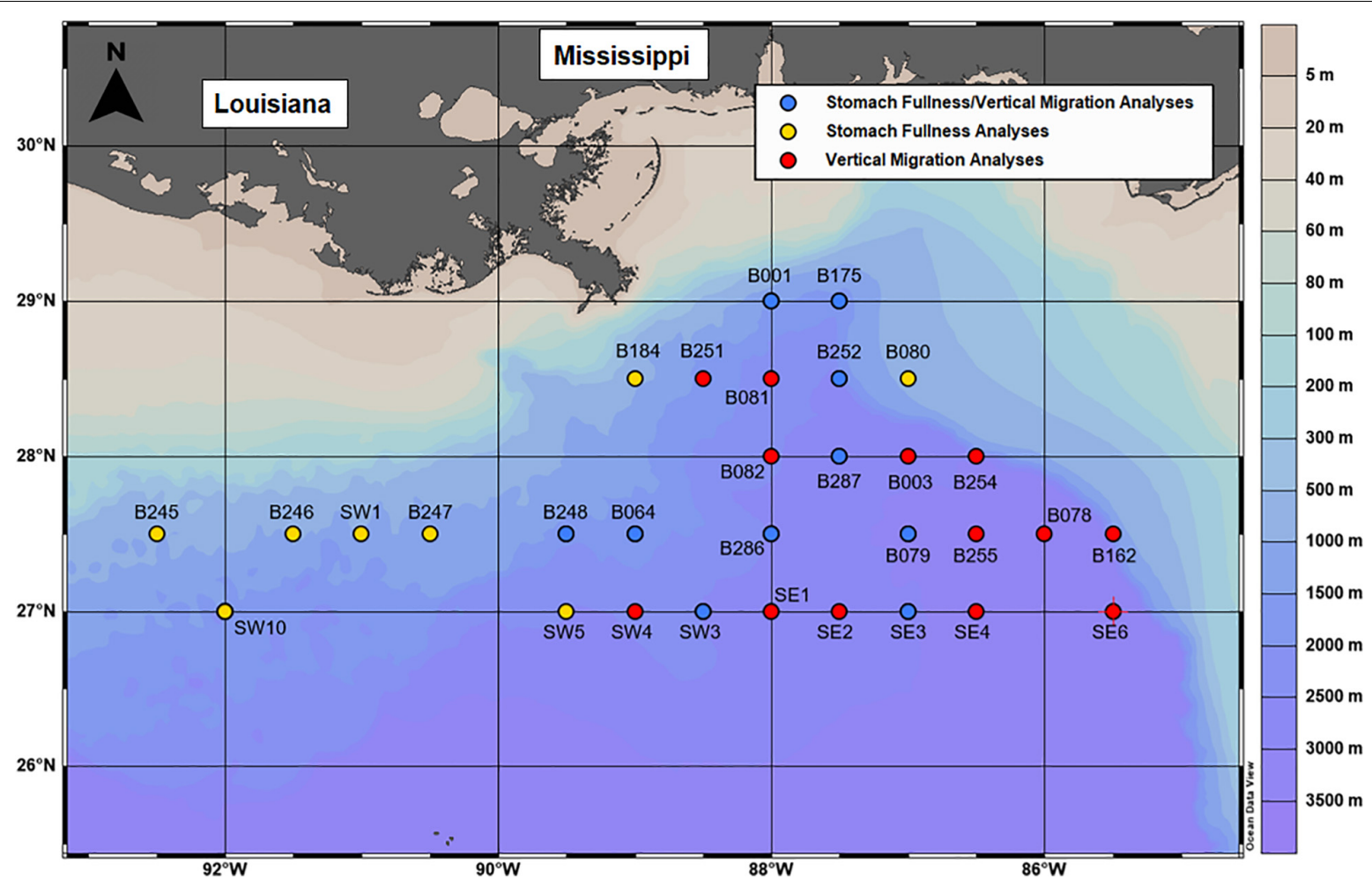

FIGURE 1 | The locations of sampled stations during ONSAP and DEEPEND. Blue, red, and yellow circles indicate locations of collections of crustacean and fish samples used for both stomach fullness/vertical migration analyses, stomach fullness analyses, and vertical migration analyses.

calipers (CO030150, Marathon Management $\left.{ }^{\circledR}\right)$. Carapace lengths were measured as the distance between the posterolateral end of the carapace and the insertion of the eyestalk, and standard lengths were measured as the distance from the anterior tip of the rostrum or lower jaw to the posterior margin of the hypural plates. The trawls included in analyses were chosen if there was a full complement of nets for which there were flow data available, and specimens for this study were selected indiscriminately from nighttime trawls conducted in Gulf Common Water (T300 $\leq 13.46^{\circ} \mathrm{C}$; Johnston et al., 2019). Selecting specimens from one water mass (Gulf Common Water) was intended to reduce potential effects imparted by physicochemical water properties rather than satiation, the focus of this study. For stomach fullness index (SFI) analyses, not all individuals of a species from a given trawl were included in analysis, as there were a lot of individuals in a given trawl (i.e., some of the trawls from ONSAP had hundreds of specimens of the same species). For calculating the mean proportion of migrants of each species, all individuals of a given species from each 2011 and 2015-2017 cruise were included in analyses, if also fitting the trawl criteria described above. If fewer than 10 individuals for any species were collected in an entire cruise, all trawls from that cruise were excluded from calculations of the mean proportion of migrants for that species.

\section{Stomach Fullness Indices}

Crustacean and fish SFI were quantitatively estimated using a scale of 0-5 [(adapted from Sutton and Hopkins (1996) and
Carmo et al. (2015)]. According to this scale, $0=$ completely empty; $1 \leq 20 \%$ of the total capacity of the stomach was filled with prey; $2=20-50 \%$ of the total capacity of the stomach was filled with prey with moderate expansion and elongation of the stomach; $3=51-70 \%$ of the total capacity of the stomach was filled with prey, with visible expansion or turgor of the stomach; $4=71-95 \%$ of the total capacity of the stomach was filled with prey; and $5 \geq 95 \%$ of the total capacity of the stomach was filled with prey with visible prey items seen through the stomach wall or prey bulging out of the recently severed connection between the buccal cavity and esophagus.

\section{Mean Proportion of Migrants}

Data from ONSAP and DEEPEND, as well as published data on nocturnal and diurnal distributions of micronektonic crustaceans and fishes (Donaldson, 1975; Roe, 1984; Hopkins et al., 1989, 1994; Burdett et al., 2017; Frank et al., 2020), were used to classify taxa as migrators or non-migrators. Only taxa identified as migratory were included in this study (Table 1). Individuals from migratory taxa were classified as being migrators or non-migrators based on their daytime depth distributions. The core daytime distributions of each species were calculated using only day trawls from all depths. Net 1 $(1,200-1,500 \mathrm{~m})$ was excluded from vertical migration analyses because very few individuals of any species in this study were found at those depths. Substantial portions of the Allosergestes pectinatus, Allosergestes sargassi, Benthosema suborbitale, 
TABLE 1 | Numerically dominant crustacean and fish species counts utilized for quantitative stomach fullness analyses.

\begin{tabular}{|c|c|c|c|c|c|c|c|c|c|c|c|}
\hline & \multicolumn{2}{|c|}{ SFI “0” } & \multicolumn{2}{|c|}{ SFI “1” } & \multicolumn{2}{|c|}{ SFI “2” } & \multicolumn{2}{|c|}{ SFI “3” } & \multicolumn{2}{|c|}{ SFI “4” } & \multirow[t]{2}{*}{ Migration group } \\
\hline & $\mathbf{M}$ & NM & M & NM & M & NM & M & NM & M & NM & \\
\hline \multicolumn{12}{|l|}{ A. Crustaceans } \\
\hline \multicolumn{12}{|l|}{ Benthesicymidae } \\
\hline Gennadas capensis & 0 & 1 & 24 & 10 & 12 & 7 & 5 & 1 & 0 & 0 & Group 2 \\
\hline Gennadas valens & 0 & 3 & 20 & 18 & 7 & 4 & 8 & 3 & 2 & 0 & Group 2 \\
\hline \multicolumn{12}{|l|}{ Oplophoridae } \\
\hline Acanthephyra purpurea & 16 & 4 & 20 & 21 & 8 & 7 & 4 & 3 & 1 & 2 & Group 1 \\
\hline Systellaspis debilis & 10 & 6 & 14 & 30 & 2 & 10 & 2 & 3 & 0 & 0 & Group 1 \\
\hline \multicolumn{12}{|l|}{ Pandalidae } \\
\hline Plesionika richardi & 28 & 0 & 15 & 16 & 1 & 7 & 0 & 3 & 0 & 0 & Group 1 \\
\hline \multicolumn{12}{|l|}{ Sergestidae } \\
\hline Gardinerosergia splendens & 13 & 3 & 20 & 13 & 3 & 5 & 0 & 0 & 0 & 0 & Group 1 \\
\hline \multicolumn{12}{|l|}{ B. Fishes } \\
\hline \multicolumn{12}{|l|}{ Myctophidae } \\
\hline Benthosema suborbitale & 0 & 1 & 20 & 18 & 13 & 3 & 5 & 3 & 4 & 1 & Group 2 \\
\hline Lampanyctus alatus & 12 & 0 & 26 & 13 & 5 & 6 & 0 & 1 & 0 & 1 & Group 1 \\
\hline Lepidophanes guentheri & 4 & 0 & 4 & 7 & 1 & 0 & 0 & 3 & 0 & 0 & Group 1 \\
\hline Notolychnus valdiviae & 7 & 0 & 3 & 7 & 2 & 3 & 0 & 0 & 0 & 0 & Group 1 \\
\hline
\end{tabular}

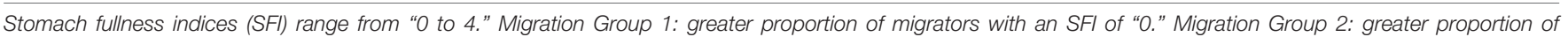
non-migrators than migrators with an SFI of "O." Families are listed in bold type. " $M$ " and "NM" denotes migrators and non-migrators, respectively.

Nematoscelis atlaticus/microps, Notolychnus valdiviae, Plesionika richardi, Sergestes atlanticus, Sergestes edwardsi, Sergestes henseni, Systellaspis debilis, Thysanopoda acutifrons/orientalis, and T. aequalis/obtusifrons subpopulations were present between 300 and $600 \mathrm{~m}$ during the day (Hopkins et al., 1994; Burdett et al., 2017; Frank et al., 2020), and these species were classified as migrators if captured at depths of $0-200 \mathrm{~m}$ at night. Acanthephyra purpurea, Gardinerosergia splendens, Gennadas capensis, Gennadas valens, Lampanyctus alatus, and Lepidophanes guentheri were primarily found below $600 \mathrm{~m}$ during the day and were classified as migrators if caught between 0 and $600 \mathrm{~m}$ at night. All of the species in this study were classified as strong migrators, based on the rationale provided by Burdett et al. (2017). Standardized abundances for each net were calculated by dividing the total counts by the total volume filtered for that net. The standardized abundances for the migrating and non-migrating subpopulations were summed for a total species abundance, and the proportion of migrants was calculated by dividing the abundance of migrators by the total species abundance. An unweighted mean was calculated to avoid statistical bias when comparing ONSAP and DEEPEND samples, as there were significantly larger catches in the ONSAP trawls that could systematically bias the analysis.

\section{Data Analysis}

The migratory taxa selected for SFI analyses are among the numerically dominant species from each deep-sea crustacean and fish family in the GoM (Hopkins et al., 1994; Burdett et al., 2017; Nichols, 2018; Milligan and Sutton, 2020). For assemblage-level analyses, the proportion of individuals with an SFI of "0" was compared between migrating and non-migrating individuals of migratory taxa during ONSAP and DEEPEND to assess whether individuals captured in shallow waters had less full stomachs than those caught at depth. This was achieved by using contingency tables and analyzing the significance of these differences with the chi-squared frequency analysis or Fisher's exact test. The key assumption that must be met when using a chi-squared analysis is that no more than $20 \%$ of the replicates can be less than five (Greenwood and Nikulin, 1996). If more than $20 \%$ of the count data had less than five replicates, the Fisher's exact test was used. Intraspecific and intrafamilial comparisons were made for crustaceans and fishes, while crustaceans were compared with fishes only at the assemblage level. During the analyses, it became clear that there were visible differences in the mean proportion of migrants for some crustacean species from samples collected 1 year after the oil spill (ONSAP) and those collected 5-7 years after the spill (DEEPEND), so statistical analyses were conducted on these data as well. The mean proportion of migrants for each species was statistically compared between ONSAP and DEEPEND cruises using Welch's $t$-test or the Mann-Whitney Rank Sum to detect changes in migration behavior between the two cruise schemes.

\section{RESULTS}

\section{Stomach Fullness Analyses}

The SFI of 588 individuals from 10 species of crustaceans and fishes were analyzed (Table 1). No individual had a completely full stomach (a " 5 " on the stomach fullness scale), and a majority (80.9\%) of individuals had partially full stomachs (13 ). The crustaceans fell into two categories-Group 1: those with a greater proportion of migrators with an SFI of " 0 " as opposed to non-migrators (A. purpurea, G. splendens, P. richardi, 

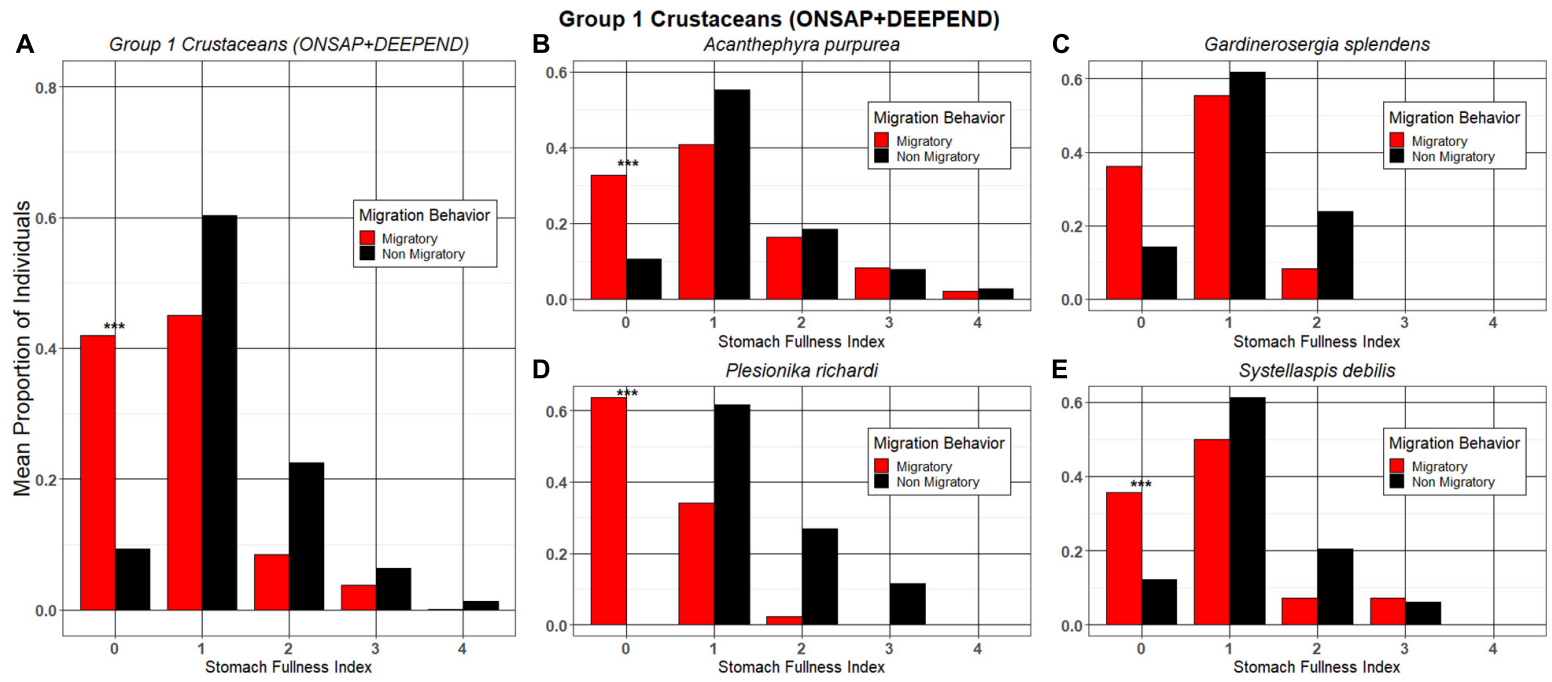

FIGURE 2 | The mean proportion of migrating and non-migrating individuals of Group 1 crustacean taxa at each stomach fullness index (SFI). (A) Group 1 crustaceans collected during ONSAP and DEEPEND (analyzed together); (B) Acanthephyra purpurea; (C) Gardinerosergia splendens; (D) Plesionika richardi; and (E) Systellaspis debilis. ${ }^{\star \star \star}$ denotes significance $(\alpha=0.05)$ between groups.

and Systellaspsis debilis) and Group 2: those with a greater proportion of non-migrators than migrators with an SFI of " 0 " (G. capensis and $G$. valens). When grouping all the crustacean species in Group 1 together from both cruises, the proportion of migrators with an SFI of "0" was significantly greater than that of the non-migrators when compared with migrators and non-migrators with SFIs "1-4," respectively (Figure 2A; Welch's $t$-test; $p=0.0068$ ). When examining trends within individual species in Group 1, the vertically migrating carideans A. purpurea, $P$. richardi, and $S$. debilis had a significantly higher proportion of migrators with an SFI of " 0 " relative to nonmigrators when compared with the migrators and non-migrators of each species with SFIs of "1-4," respectively (Fisher's exact; $p=0.0177 ; p=0.0083$; respectively; chi-squared; $p=0.0146$, Figures $2 \mathrm{~B}, \mathrm{D}, \mathrm{E})$. The same trend was observed for $G$. splendens individuals, although these differences were not statistically significant (Fisher's exact; $p=0.1259$; Figure 2C).

For the Group 2 crustaceans, which were both Gennadas species in the family Benthesicymidae, a higher proportion of individuals with an SFI of "0" were present in the non-migrators compared with the migrators, but these differences were not statistically significant (Mann-Whitney; $p=0.212$; Figure 3A), and there was no significant difference between the proportion of migrators and non-migrators with an SFI of " 0 " (G. capensis; Fisher's exact; $p=0.4921 ; G$. valens; $p=0.0566$; respectively; Figures 3B-C).

The fishes also fell into the two categories as described above for the crustaceans: Group 1 (L. alatus, L. guentheri, and $N$. valdiviae) and Group 2 (B. suborbitale). When grouping all migratory fish species together from Group 1, individuals that undertook a nocturnal ascent had a significantly higher proportion of individuals with an SFI of " 0 " as opposed to those that refrained from migrating (Welch's $t$-test; $p=0.0190$; Figure 4A).
Looking at individual species, the vertically migrating myctophids L. alatus and N. valdiviae had a significantly higher proportion of migrators with an SFI of " 0 " relative to nonmigrators (Fisher's exact, $p=0.0013, p=0.0053$, Figures 4B,D), whereas data for L. guentheri and the Group 2 fish B. suborbitale indicated that there were no significant differences between the proportion of migrators and non-migrators with an SFI of " 0 " (Fisher's exact, $p=0.0823$, Figure 4C, Fisher's exact, $p=0.3824$, Figure 4E).

\section{Vertical Migration Analyses}

Four of the 14 species (A. sargassi, S. atlanticus, S. edwardsi, and $N$. atlantica/microps) had a significantly higher mean proportion of migrants during DEEPEND relative to ONSAP (Table 2). In contrast, there was a significant decrease in mean proportion of migrants for T. acutifrons/orientalis during DEEPEND relative to ONSAP. Although the mean proportion of migrants during DEEPEND was higher for G. splendens, $G$. capensis, G. valens, P. richardi, and S. henseni, and lower for A. purpurea, S. debilis, and T. aequalis/obtusifrons, these differences were not statistically significant, indicating no change in migration behavior for these species.

There was a substantially greater proportion of migrating individuals (0.56) in the Group 1 crustaceans with an SFI of "0" during ONSAP (one year after the oil spill) compared to non-migrators (0.12), and this difference was not statistically significant (Welch's $t$-test, $p=0.0867$, Figure 5A). However, for the DEEPEND (5-7 years after the spill) samples, a significantly higher proportion of migrating individuals had an SFI of " 0 " relative to non-migrators (Welch's $t$-test, $p=0.0395$ ), suggesting a significant change in migration behavior between the two cruise schemes. For the Group 2 crustaceans, there were no significant differences between the migrating vs. non-migrating 

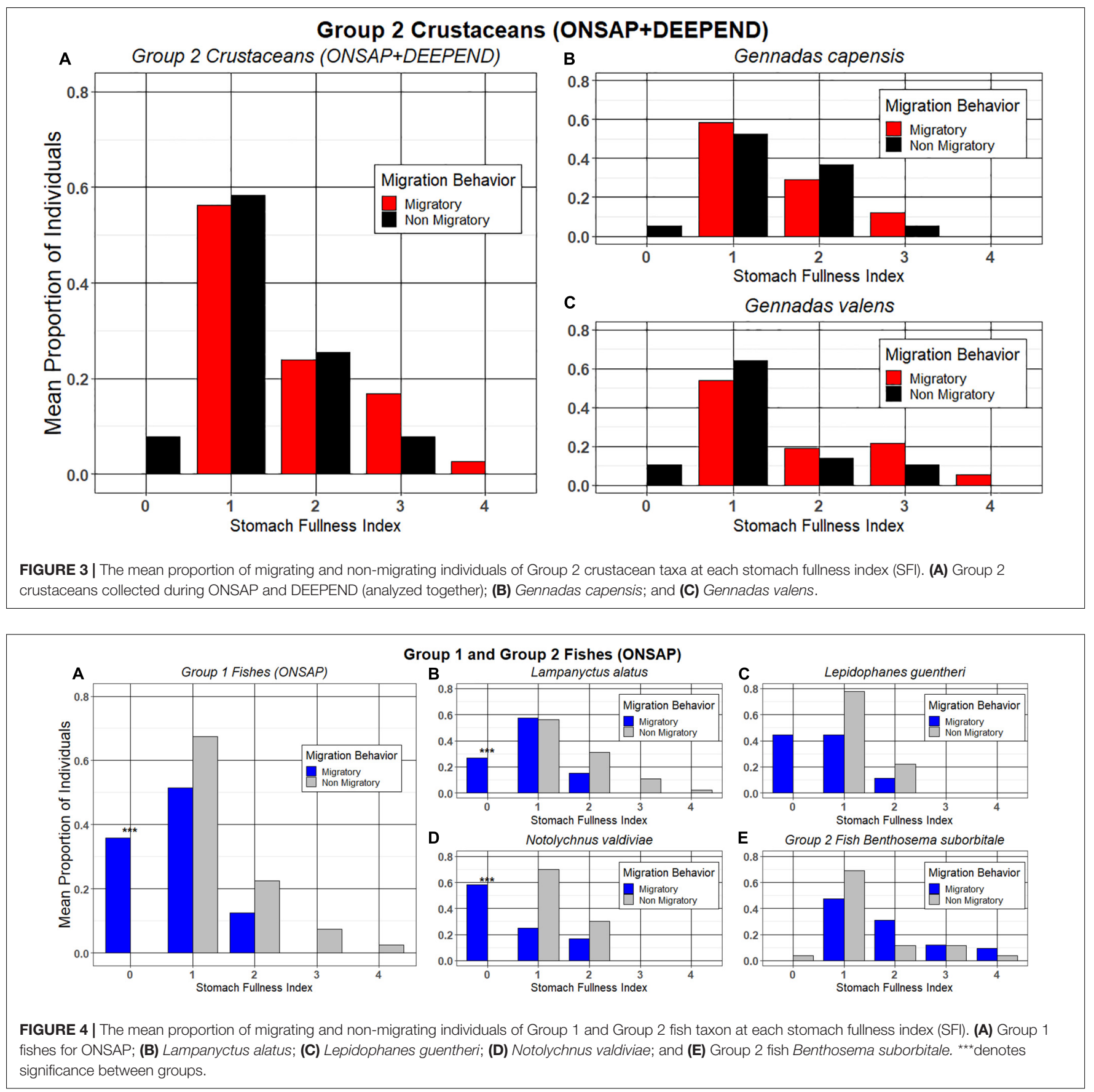

subpopulations for ONSAP (Mann-Whitney, $p=0.0786$ ) and DEEEPEND (Welch's $t$-test, $p=0.8413$, Figure 5B).

\section{DISCUSSION}

\section{Evidence or Lack Thereof for the Hunger-Satiation Hypothesis}

Discrete-depth abundance and distribution data from ONSAP (2011) and DEEPEND (2015-2017) confirm that numerically dominant mesopelagic fishes and shrimps undertake "asynchronous" vertical migrations (i.e., some individuals of a population migrate each night while some do not; Table 2). This phenomenon has been reported previously in the GoM and elsewhere (Hopkins et al., 1989, 1994; Hopkins and Gartner, 1992; Onsrud and Kaartvedt, 1998; Kaartvedt et al., 2009; Dypvik et al., 2012). Quantitative stomach fullness indices for the non-migrating portions of Group 1 crustaceans (A. purpurea, P. richardi, G. splendens, and S. debilis) and Group 1 fishes (L. alatus, $L$. guentheri, and $N$. valdiviae) suggest that being partially sated (SFI 1-3) may lead individuals to forego daily migration behavior, whereas an individual with an SFI of " 0 " is 
TABLE 2 | The mean proportion of migrants of numerically abundant migratory crustacean taxa between ONSAP (2011) and DEEPEND (2015-2017).

\begin{tabular}{|c|c|c|c|c|}
\hline Species & $\begin{array}{l}\text { Mean proportion } \\
\text { of migrants } \\
\text { (ONSAP) }\end{array}$ & $\begin{array}{l}\text { Mean proportion } \\
\text { of migrants } \\
\text { (DEEPEND) }\end{array}$ & $\begin{array}{c}\text { Difference between mean } \\
\text { proportions (DEEPEND } \\
\text { minus ONSAP) }\end{array}$ & $\begin{array}{c}p \text {-value } \\
\text { (Mann-Whitney } \\
\text { test) }\end{array}$ \\
\hline Acanthephyra purpurea & 0.93 & 0.88 & -0.05 & 0.5580 \\
\hline Allosergestes pectinatus & 0.94 & 0.92 & -0.02 & 0.9914 \\
\hline Allosergestes sargassi & 0.74 & 0.94 & 0.20 & $0.0498^{\star \star \star}$ \\
\hline Gardinerosergia splendens & 0.67 & 0.76 & 0.09 & 0.1659 \\
\hline Gennadas capensis & 0.70 & 0.85 & 0.15 & 0.4153 \\
\hline Gennadas valens & 0.86 & 0.91 & 0.05 & 0.0624 \\
\hline Nematoscelis atlantica/microps & 0.63 & 0.81 & 0.17 & $0.0060^{\star \star \star}$ \\
\hline Plesionika richardi & 0.83 & 0.91 & 0.08 & 0.0638 \\
\hline Sergestes atlanticus & 0.94 & 1.00 & 0.06 & $0.0059^{\star \star \star}$ \\
\hline Sergestes henseni & 0.70 & 0.73 & 0.03 & 0.0712 \\
\hline Sergestes edwardsi & 0.79 & 0.99 & 0.20 & $0.0054^{\star \star \star}$ \\
\hline Systellaspis debilis & 0.77 & 0.63 & -0.14 & 0.6956 \\
\hline Thysanopoda acutifrons/orientalis & 0.30 & 0.12 & -0.18 & $0.0332^{\star \star \star}$ \\
\hline Thysanopoda aequalis/obtusifrons & 0.96 & 0.84 & -0.12 & 0.2221 \\
\hline
\end{tabular}

${ }^{* * *}$ denotes statistical significance between cruises. This table only includes crustacean taxa.

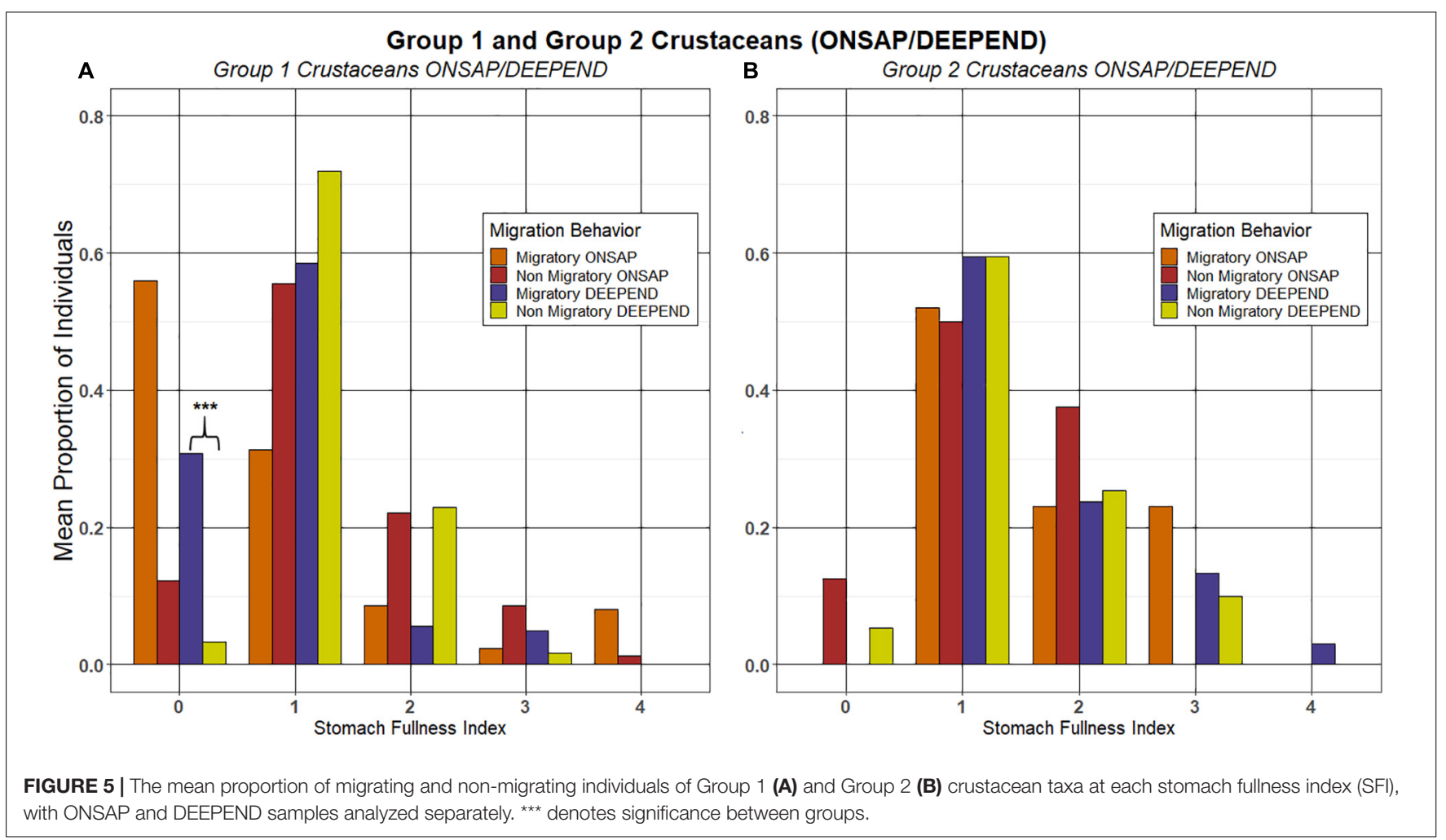

more likely to vertically migrate (Table 1 and Figures 2A-E, 4AD). If partially sated, the metabolic cost of swimming upward hundreds of meters may be avoided. Stomach fullness data from Foxton and Roe (1974), Donaldson (1975), Heffernan and Hopkins (1981), Roe (1984), Hopkins and Sutton (1998), and Podeswa (2012) confirm that A. purpurea, G. splendens, L. alatus, L. guentheri, N. valdiviae, $P$. richardi, and $S$. debilis feed primarily at night. These conclusions were based on the observations that either stomach fullness indices were higher or gut contents less digested, for nighttime, surface-sampled individuals when compared to individuals captured in deep waters. None of these studies statistically compared stomach fullness indices between the migrating and non-migrating subpopulations. The trend observed for 7 of the 10 species targeted in the present study was a higher mean proportion of migrating individuals with an SFI of "0" relative to the non-migrating subpopulation, with data for A. purpurea, L. alatus, N. valdiviae, P. richardi, and S. debilis being statistically significant (Table 1 and Figures 2, 4). 
Observations of diet composition by Foxton and Roe (1974), Merrett and Roe (1974), Donaldson (1975), Clarke (1978), Roe (1984), Flock and Hopkins (1992), and Podeswa (2012) suggest the possibility of feeding at depth during the day by A. purpurea, G. splendens, G. capensis, G. valens, L. alatus, $L$. guentheri, N. valdiviae, P. richardi, and S. debilis. For example, Foxton and Roe (1974) noted the presence of the ostracod Conchoecia lophura, which is distributed between 400 and $600 \mathrm{~m}$ during night and day, in the foregut of $S$. debilis collected from $250 \mathrm{~m}$ at sunset. This observation suggests that either this prey item was consumed earlier in S. debilis' migration or at depth during the day. The few data on complete stomach evacuation that are available for decapod crustaceans range from 1-13 h under normal circumstances to 2-3 days in laboratory studies with starved organisms (Omori, 1974; Murtaugh, 1984). However, Murtaugh's 1984 calculation is based on the coastal species Neomysis mercedis, which has a different life-history than deep-pelagic organisms and should therefore be viewed with caution. Based on Murtaugh's 1984 observations, Mincks et al. (2000) recommended using $6 \mathrm{~h}$ as the average time of stomach evacuation and implemented this estimate for calculating vertical particle flux by deep-pelagic crustaceans. Integrating this estimate with data from the present study suggests that the non-migrating individuals of migrating taxa with SFIs $>0$ fed successfully during the day at their normal daytime depths rather than digesting food left over from the previous night's migration.

The migration behavior of the Group 2 crustaceans (G. capensis and G. valens) was not associated with their state of satiation in terms of having completely empty stomachs (Table 1 and Figures 3A-C). Previous studies in the GoM and North Atlantic Ocean on various species of Gennadas found that a large portion of the population did not migrate (Heffernan and Hopkins, 1981; Hopkins et al., 1994) or appeared to spread upward rather than migrating as a compact unit (Roe, 1984). Gut content analyses showed that the guts contained a large portion of greenish material likely to be detritus or marine snow (Heffernan and Hopkins, 1981; Roe, 1984; Mincks et al., 2000), and two of these studies from the northeast Atlantic and Arabian Sea suggested that Gennadas feeds continuously throughout its depth range (Roe, 1984; Mincks et al., 2000). These observations provide an explanation for why some individuals may refrain from undertaking the nocturnal ascent, as a large portion of their food is plentiful at their daytime depths (Donaldson, 1975; Heffernan and Hopkins, 1981; Hopkins et al., 1994). If Gennadas individuals were refraining from migrating to preferentially feed on marine snow or another prey item at depth to conserve energy, it would be expected that non-migrators would have a smaller percentage of individuals with an SFI of "0" relative to migrators. However, there was no significant difference between the percentage of migrators vs. non-migrators with an SFI $=0$, and none of the migrators had completely empty stomachs. Heffernan and Hopkins (1981) also reported that $<5 \%$ of migrating G. capensis and G. valens possessed empty stomachs. As Gennadas appears to feed continuously throughout its depth range and does not display any consistent diel feeding pattern (Roe, 1984; Mincks et al., 2000), it is also possible that migrating individuals started their migrations with an SFI of " 0 " and fed at deeper depths early in their migrations.

The migration pattern of the Group 1 fishes ( $L$. alatus, $L$. guentheri, and $N$. valdiviae) appeared to be associated with state of satiation (Table 1 and Figures 4B-D), whereas that was not the case for the only Group 2 fish (B. suborbitale; Table 1 and Figure 4E). All four of these species are strong vertical migrators that preferentially consume the deep-dwelling, strongly migrating copepod forage taxon Pleuromamma (Hopkins et al., 1996), with L. alatus and B. suborbitale consuming nearly identical numbers (Hopkins and Baird, 1985), so it is not immediately clear why the migratory behavior of $B$. suborbitale was not correlated with state of satiation. It is possible that B. suborbitale may have a faster metabolism than L. alatus, L. guentheri, and N. valdiviae and thus has an increased need to migrate because of its active lifestyle. Myctophids like B. suborbitale with large eyes and silvery scales are thought to be strong vertical migrators that follow isolumes (Barham, 1971), as opposed to less active myctophids like L. alatus, L. guentheri, and $N$. valdiviae with relatively small eyes and all black bodies. Another potential reason for the lack of a correlation between state of satiation and migratory behavior in B. suborbitale may be that $B$. suborbitale has a shallower core daytime range (200-600 m) than L. alatus and L. guentheri $(200-1,000 \mathrm{~m})$ in the northern GoM (Gartner, 1993; Hopkins et al., 1996). Therefore, it has to migrate shorter distances to get to shallower waters. N. valdiviae also has a core daytime range of 200-600 m (Gartner, 1993; Hopkins et al., 1996), and it could be expected that it would behave similarly to B. suborbitale. However, $N$. valdiviae has been reported to feed on a broader spectrum of prey when copepods are not available for consumption (Merrett and Roe, 1974), and this observation might explain the smaller proportion of migrants of that species relative to B. suborbitale. For energy conservation purposes, it is possible that a desired state of satiation outweighs the need to invest energy in vertical migrations, and this may be proportional to the distance that must be traveled to reach the desired prey. Thus, non-migrating $L$. alatus, $L$. guentheri, and $N$. valdiviae may be more ecomorphologically and physiologically suited to refrain from migrating relative to $B$. suborbitale individuals.

Interestingly, there was a significantly higher proportion of Group 1 migrators with SFI " 0 " when compared with the Group 1 non-migrators for the DEEPEND cruises, whereas no significant difference was found for either the Group 1 migrators and non-migrators for ONSAP (Figure 5A), as well as the Group 2 crustaceans for ONSAP and DEEPEND (Figure 5B). In addition, there was a statistically significant increase in the mean proportion of migrants for the sergestids A. sargassi, S. atlanticus, S. edwardsi, and the euphausiid N. atlantica/microps between the ONSAP and DEEPEND datasets (Table 2). Ursella et al. (2018) postulated that migration behavior in zooplankton was not a mandatory behavior and this was related to food availability in deeper waters and environmental conditioning (i.e., if less food is available at depth, more zooplankton would migrate). However, there were no significant differences in migration behavior or SFI between ONSAP and DEEPEND samples for the Group 1 crustaceans A. purpurea, G. splendens, P. richardi, and S. debilis 
for which satiation data are available, and the same was true for the Group 2 benthesicymids G. capensis and $G$. valens, as well as the sergestids $A$. pectinatus and $S$. henseni and the euphausiid $T$. aequalis/obtusifrons. In addition, a significant decrease in migration behavior was observed for $T$. acutifrons/orientalis. While there are differences in preferred prey/feeding mode for some of the species, there are no data on any changes in zooplankton abundances in the GoM during the period of the current study, so the reason for the changes or lack thereof in migration behavior remains to be determined and warrants further investigation.

\section{CONCLUSION}

In conclusion, results from this study provide the first statistically rigorous support for a key aspect of the HungerSatiation hypothesis, that state of satiation is correlated with vertical migration behavior in asynchronous vertical migrators, which in this case are numerically dominant components of a low-latitude mesopelagic ecosystem. The biogeochemical impact of vertical migration is a global-scale phenomenon given the immense size of the mesopelagic realm. Thus, understanding the drivers of vertical migration is critically important, especially given the changes predicted to occur based on climate change.

\section{DATA AVAILABILITY STATEMENT}

The raw data supporting the conclusions of this article will be made available by the authors, without undue reservation.

\section{REFERENCES}

Alldredge, A. L., and King, J. M. (1980). Effects of moonlight on the vertical migration patterns of demersal zooplankton. J. Exp. Mar. Biol. Ecol. 44, $133-$ 156. doi: 10.1016/0022-0981(80)90150-1

Atkinson, A., Ward, P., and Poulet, S. A. (1992). Feeding rates and diel vertical migration of copepods near South Georgia: comparison of shelf and oceanic sites. Mar. Biol. 114, 49-56.

Barham, E. G. (1971). “Deep-sea fishes: lethargy and vertical orientation,” in Proceedings of an International Symposium on Biological Sound Scattering in the Ocean, ed. G. B. Farquha (Washington, DC: Superintendent of Ducuments), 100-118.

Bennett, W. A., Kimmerer, W. J., and Burau, J. R. (2002). Plasticity in vertical migration by native and exotic estuarine fishes in a dynamic low-salinity zone. Limnol. Oceanogr. 47, 1496-1507. doi: 10.4319/lo.2002.47.5.1496

Bianchi, D., Galbraith, E. D., Carozza, D. A., Mislan, K. A. S., and Stock, C. A. (2013). Intensification of open-ocean oxygen depletion by vertically migrating animals. Nat. Geosci. 6, 545-548. doi: 10.1038/ngeo1837

Bollens, S. M., and Frost, B. W. (1989). Predator-induced diet vertical migration in a planktonic copepod. J. Plankton Res. 11, 1047-1065. doi: 10.1093/plankt/11. 5.1047

Bollens, S. M., Rollwagen-Bollens, G. C., Quenette, J., and Bochdansky, A. B. (2011). Cascading migrations, and implications for vertical fluxes in pelagic ecosystems. J. Plankton Res. 33, 349-355. doi: 10.1093/plankt/fbq152

\section{ETHICS STATEMENT}

Ethical review and approval was not required for this animal study because these vertebrate animals were deceased prior to experimentation.

\section{AUTHOR CONTRIBUTIONS}

$\mathrm{RB}, \mathrm{TS}$, and TF conceptualized the project idea. TS and TF collected the field samples and identified the species used in this study. RB conducted the research, analyzed the data, and wrote the manuscript, with guidance from TS and TF. TF oversaw all aspects of the project. All authors have agreed to being listed as such and approve of the submitted version of this manuscript.

\section{FUNDING}

This project was funded in part by the NOAA Office of Response and Restoration and in part by a grant from the Gulf of Mexico Research Initiative. Data are publicly available through the Gulf of Mexico Research Initiative Information and Data Cooperative (GRIIDC) at https://data.gulfresearchinitiative.org (doi: 10.7266/N7VX0DK2, 10.7266/N70P0X3T, 10.7266/N7XP7385, and $10.7266 /$ N7902234).

\section{ACKNOWLEDGMENTS}

We thank the captains and crews of the M/V Meg Skansi and $\mathrm{R} / \mathrm{V}$ Point Sur for excellent ship time services. We would also like to thank Devan Nichols, Michael Novotny, Nathan LaSpina, Nina Pruzinsky, Richard Hartland, and Ronald Sieber for sample processing assistance.

Burdett, E. A., Fine, C. D., Sutton, T. T., Cook, A. B., and Frank, T. M. (2017). Geographic and depth distributions, ontogeny, and reproductive seasonality of decapod shrimps (Caridea: Oplophoridae) from the northeastern Gulf of Mexico. Bull. Mar. Sci. 93, 743-767. doi: 10.5343/bms.2016.1083

Carmo, V., Sutton, T. T., Menezes, G., Falkenhaug, T., and Bergstad, O. A. (2015). Feeding ecology of the Stomiiformes (Pisces) of the northern MidAtlantic Ridge. 1. The Sternoptychidae and Phosichthyidae. Prog. Oceanogr. 130, 172-187. doi: 10.1016/j.pocean.2014.11.003

Clark, C. W., and Levy, D. A. (1988). Diel vertical migrations by juvenile sockeye salmon and the antipredation window. Am. Natural. 131, 271-290. doi: 10. $1086 / 284789$

Clarke, G. L. (1930). Change of phototropic and geotropic signs in daphnia induced by changes of light intensity. J. Exp. Biol. 7, 109-131.

Clarke, G. L. (1934). Further observations on the diurnal migration of copepods in the Gulf of Maine. Biol. Bull. 67, 432-455. doi: 10.2307/1537523

Clarke, T. A. (1978). Diel feeding patterns of 16 species of mesopelagic fishes from Hawaiian waters. Fish. Bull. US 76, 495-513.

Cohen, J., and Forward, R. (2005). Diel vertical migration of the marine copepod Calanopia americana. I. Twilight DVM and its relationship to the diel light cycle. Mar. Biol. 147, 387-398. doi: 10.1007/s00227-005-1569-x

Dam, H. G., Roman, M. R., and Youngbluth, M. J. (1995). Downward export of respiratory carbon and dissolved inorganic nitrogen by diel-migrant mesozooplankton at the JGOFS Bermuda time-series station. Deep Sea Res. I 42, 1187-1197. doi: 10.1016/0967-0637(95)00048-B 
Donaldson, H. A. (1975). Vertical distribution and feeding of sergestid shrimps (Decapoda: Natantia) collected near Bermuda. Mar. Biol. 31, 37-50. doi: 10. 1007/BF00390646

Dypvik, E., Røstad, A., and Kaartvedt, S. (2012). Seasonal variations in vertical migration of glacier lanternfish, Benthosema glaciale. Mar. Biol. 159, 16731683. doi: 10.1007/s00227-012-1953-2

Flock, M. E., and Hopkins, T. L. (1992). Species composition, vertical distribution, and food habits of the sergestid shrimp assemblage in the eastern Gulf of Mexico. J. Crustac. Biol. 12, 210-223. doi: 10.2307/1549076

Forward, R. (1988). Diel vertical migration: zooplankton photobiology and behaviour. Oceanogr. Mar. Biol. Annu. Rev. 26, 1-393.

Foxton, P., and Roe, H. (1974). Observations on the nocturnal feeding of some mesopelagic decapod Crustacea. Mar. Biol. 28, 37-49. doi: 10.1007/BF00389115

Frank, T. M., Fine, C. D., Burdett, E. A., Cook, A. B., and Sutton, T. T. (2020). The vertical and horizontal distribution of deep-sea crustaceans in the Order Euphausiacea in the vicinity of the Deepwater Horizon oil spill. Front. Mar. Sci. 7:99. doi: 10.3389/fmars.2020.00099

Gartner, J. V. (1993). Patterns of reproduction in the dominant lanternfish species (Pisces: Myctophidae) of the eastern Gulf of Mexico, with a review of reproduction among tropical-subtropical Myctophidae. Bull. Mar. Sci. 52, 721-750.

Geller, W. (1986). Diurnal vertical migration of zooplankton in a temperate great lake (L. Constance): a starvation avoidance mechanism? Arch. Hydrobiol. 74, 675-694.

Gibbons, M. J. (1993). Vertical migration and feeding of Euphausia lucens at two 72 $\mathrm{h}$ stations in the southern Benguela upwelling region. Mar. Biol. 116, 257-268. doi: 10.1007/BF00350016

Gjøsaeter, J., and Kawaguchi, K. (1980). A Review of the World Resources of Mesopelagic Fish. Rome: Food and Agriculture Organization.

Greenwood, P. E., and Nikulin, M. S. (1996). A Guide to Chi-Squared Testing, Vol. 280. Hoboken, NJ: John Wiley \& Sons.

Haney, J. F. (1993). Environmental control of did vertical migration behavior. Arch. Hydrobiol. Beih. Ergebn. Limnol. 39, 1-17.

Heffernan, J. J., and Hopkins, T. L. (1981). Vertical distribution and feeding of the Shrimp Genera Gennadas and Bentheogennema (Decapoda: Penaeidea) in the Eastern Gulf of Mexico. J. Crustacean Biol. 37, 461-473. doi: 10.2307/154 8124

Hidaka, K., Kawaguchi, K., Murakami, M., and Takahashi, M. (2001). Downward transport of organic carbon by diel migratory micronekton in the western equatorial Pacific: its quantitative and qualitative importance. Deep Sea Res. I 48, 1923-1939. doi: 10.1016/S0967-0637(01)00003-6

Hill, A. E. (1991). A mechanism for horizontal zooplankton transport by vertical migration in tidal currents. Mar. Biol. 111, 485-492. doi: 10.1007/BF01319422

Hopkins, T. L., and Baird, R. C. (1985). Aspects of the trophic ecology of the mesopelagic fish Lampanyctus alatus (Family Myctophidae) in the eastern Gulf of Mexico. Biol. Oceanogr. 3, 285-313.

Hopkins, T. L., Flock, M. E., Gartner, J. V. Jr., and Torres, J. J. (1994). Structure and trophic ecology of a low latitude midwater decapod and mysid assemblage. Mar. Ecol. Prog. Ser. 109, 143-156. doi: 10.3354/meps109143

Hopkins, T. L., and Gartner, J. V. (1992). Resource-partitioning and predation impact of a low-latitude myctophid community. Mar. Biol. 114, 185-197. doi: 10.1007/BF00349518

Hopkins, T. L., Gartner, J. V., and Flock, M. E. (1989). The caridean shrimp (Decapoda: Natantia) assemblage in the mesopelagic zone of the eastern Gulf of Mexico. Bull. Mar. Sci. 45, 1-14.

Hopkins, T. L., Sutton, T. T., and Lancraft, T. M. (1996). The trophic structure and predation impact of a low latitude midwater fish assemblage. Prog. Oceanogr. 38, 205-239. doi: 10.1016/S0079-6611(97)00003-7

Hopkins, T. L., and Sutton, T. T. (1998). Midwater fishes and crustaceans as competitors and resource partitioning in low latitude oligotrophic ecosystems. Mar. Ecol. Prog. Ser. 164, 37-45. doi: 10.3354/meps164037

Hu, V. J. H. (1978). Relationships between vertical migration and diet in four species of euphausiids 1. Limnol. Oceanogr. 23, 296-306. doi: 10.4319/lo.1978. 23.2.0296

Huntley, M., and Brooks, E. R. (1982). Effects of age and food availability on diel vertical migration of Calanus pacificus. Mar. Biol. 71, 23-31. doi: 10.1007/ BF00396989
Johnston, M. W., Milligan, R. J., Easson, C. G., deRada, S., English, D. C., et al. (2019). An empirically validated method for characterizing pelagic habitats in the Gulf of Mexico using ocean model data. Limnol. Oceanogr. Methods 17, 362-375. doi: 10.1002/lom3.10319

Kaartvedt, S., Røstad, A., Klevjer, T. A., and Staby, A. (2009). Use of bottommounted echo sounders in exploring behavior of mesopelagic fishes. Mar. Ecol. Prog. Ser. 395, 109-118. doi: 10.3354/meps08174

Kaartvedt, S., Staby, A., and Aksnes, D. L. (2012). Efficient trawl avoidance by mesopelagic fishes causes large underestimation of their biomass. Mar. Ecol. Prog. Ser. 456, 1-6. doi: 10.3354/meps09785

Kozhov, M. M. (1947). Animals of the Lake Baikal. Irkutak: OGIZ.

Longhurst, A. R. (1976). Interactions between zooplankton and phytoplankton profiles in the eastern tropical Pacific Ocean. Deep Sea Res. Oceanogr. 23, 729-754. doi: 10.1016/S0011-7471(76)80017-4

Merrett, N., and Roe, H. S. J. (1974). Patterns and selectivity in the feeding of certain mesopelagic fishes. Mar. Biol. 28, 115-126. doi: 10.1007/BF00396302

Milligan, R. J., and Sutton, T. T. (2020). Dispersion overrides environmental variability as a primary driver of the horizontal assemblage structure of the mesopelagic fish family Myctophidae in the northern Gulf of Mexico. Front. Mar. Sci. 7:15. doi: 10.3389/fmars.2020.00015

Mincks, S. L., Bollens, S. M., Madin, L. P., Horgan, E., Butler, M., et al. (2000). Distribution, abundance, and feeding ecology of decapods in the Arabian Sea, with implications for vertical flux. Deep Sea Res. Part II Top. Stud. Oceanogr. 47, 1475-1516. doi: 10.1016/S0967-0645(99)00151-4

Mullin, M. M. (1963). Some factors affecting the feeding of the marine copepods of the genus Calanus. Limnol. Oceanogr. 8, 239-250. doi: 10.4319/lo.1963.8.2. 0239

Murtaugh, P. A. (1984). Variable gut residence time: problems in inferring feeding rate from stomach fullness of a mysids crustacean. Can. J. Fish. Aquat. Sci. 41, 1287-1293. doi: 10.1139/f84- 157

Nichols, D. (2018). A Temporal Analysis of a Deep-Pelagic Crustacean Assemblage (Decapoda: Caridea: Oplophoridae and Pandalidae) in the Gulf of Mexico After the Deepwater Horizon Oil Spill. Master's thesis. Fort Lauderdale, FL: Nova Southeastern University.

Omori, M. (1974). The biology of Pelagic shrimps in the ocean. Adv. Mar. Biol. 12, 233-324. doi: 10.1016/S0065-2881(08)60459-9

Onsrud, M. S. R., and Kaartvedt, S. (1998). Diel vertical migration of the krill Meganyctiphanes norvegica in relation to physical evironment, food and predators. Mar. Ecol. Prog. Ser. 171, 209-219. doi: 10.3354/meps171209

Pearre, S. (2003). Eat and run? The hunger/satiation hypothesis in vertical migration: history, evidence and consequences. Biol. Rev. 78, 1-79. doi: 10. 1017/S146479310200595X

Podeswa, Y. (2012). Active Carbon Transport and Feeding Ecology of Pelagic Decapods in the North Pacific Subtropical Gyre. Vancouver, BC: University of British Columbia.

Ponomareva, L. A. (1971). Circadian migrations and feeding rhythm of some Indian Ocean Euphauisiid Species. Oceanology 11, 226-231.

Ringelberg, J., and van Gool, E. (2003). On the combined analysis of proximate and ultimate aspects in diel vertical migration (DVM) research. Hydrobiologia 491, 85-90. doi: 10.1023/A:1024407021957

Roe, H. S. J. (1984). The diel migrations and distributions within a Mesopelagic community in the North East Atlantic. 2. Vertical migrations and feeding of Mysids and decapod crustacea. Prog. Oceanogr. 13, 269-318. doi: 10.1016/ 0079-6611(84)90011-9

Simard, Y., Lacroix, G., and Legendre, L. (1985). In situ twilight grazing rhythm during diel vertical migrations of a scattering layer of Calanus finmarchicus 1. Limnol. Oceanogr. 30, 598-606. doi: 10.4319/lo.1985.30.3.0598

Steinberg, D. K., Cope, J. S., Wilson, S. E., and Kobari, T. (2008). A comparison of mesopelagic mesozooplankton community structure in the subtropical and subarctic North Pacific Ocean. Deep Sea Res. II. 55, 1615-1635. doi: 10.1016/j. dsr2.2008.04.025

Steinberg, D. K., Goldthwait, S. A., and Hansell, D. A. (2002). Zooplankton vertical migration and the active transport of dissolved organic and inorganic nitrogen in the Sargasso Sea. Deep Sea Res. I 49, 1445-1461. doi: 10.1016/S0967-0637(02) 00037-7

Sutton, T. T., Frank, T. M., Romero, I. C., and Judkins, H. (2020). "Chapter 24: As Gulf oil extraction goes deeper, who is at risk? Community structure, 
distribution, and connectivity of the deep-pelagic fauna," in Scenarios and Responses to Future Deep Oil Spills - Fighting the Next War, eds S. A. Murawski, C. Ainsworth, S. Gilbert, D. Hollander, C. B. Paris, M. Schlüter, et al. (Berlin: Springer). doi: 10.1007/978-3-030-12963-7_24

Sutton, T. T., and Hopkins, T. L. (1996). Trophic ecology of the stomiid (Pisces: Stomiidae) fish assemblage of the eastern Gulf of Mexico: strategies, selectivity and impact of a top mesopelagic predator group. Mar. Biol. 127, 179-192. doi: 10.1007/BF00942102

Tarling, G. A., and Johnson, M. L. (2006). Satiation gives krill that sinking feeling. Curr. Biol. 16, R83-R84. doi: 10.1016/j.cub.2006. 01.044

Ursella, L., Cardin, V., Batistić, M., Garić, R., and Gačić, M. (2018). Evidence of zooplankton vertical migration from continuous Southern Adriatic buoy current-meter records. Prog. Oceanogr. 167, 78-96. doi: 10.1016/j.pocean.2018. 07.004

Waterman, T. H., Nunnemacher, R. F., Chace, F. A. Jr., and Clarke, G. L. (1939). Diurnal vertical migrations of deep-water plankton. Biol. Bull. 76, 256-279. doi: $10.2307 / 1537864$
Wiebe, P. H., Burt, K. H., Boyd, S. H., and Morton, A. W. (1976). A multiple opening/closing net and environmental sensing system for sampling zooplankton. J. Mar. Res. 34, 313-326.

Youngbluth, M. J., Bailey, T. G., Davoll, P. J., Jacoby, C. A., Blades-Eckelbarger, P. I., et al. (1989). Fecal pellet production and diel migratory behavior by the euphausiid Meganyctiphanes norvegica effect benthic-pelagic coupling. Deep Sea Res. A 36, 1491-1501. doi: 10.1016/0198-0149(89)90053-8

Conflict of Interest: The authors declare that the research was conducted in the absence of any commercial or financial relationships that could be construed as a potential conflict of interest.

Copyright $\odot 2021$ Bos, Sutton and Frank. This is an open-access article distributed under the terms of the Creative Commons Attribution License (CC BY). The use, distribution or reproduction in other forums is permitted, provided the original author(s) and the copyright owner(s) are credited and that the original publication in this journal is cited, in accordance with accepted academic practice. No use, distribution or reproduction is permitted which does not comply with these terms. 